\title{
Tracing sources of natural organic matter, trihalomethanes and metals in groundwater from a karst region
}

\author{
Connie O'Driscoll \\ Trinity College Dublin, Ireland, connieodriscoll@gmail.com \\ Eoin McGillicuddy \\ Technological University Dublin, eoin.mcgillicuddy@tudublin.ie \\ Peter Croot \\ National University of Ireland, Galway
}

See next page for additional authors

Follow this and additional works at: https://arrow.tudublin.ie/scschcpsart

Part of the Civil Engineering Commons, Environmental Engineering Commons, Environmental Health and Protection Commons, Natural Resources and Conservation Commons, Other Civil and Environmental Engineering Commons, and the Water Resource Management Commons

\section{Recommended Citation}

O'Driscoll, C., McGillicuddy, E., Croot, P. et al. Tracing sources of natural organic matter, trihalomethanes and metals in groundwater from a karst region. Environ Sci Pollut Res 27, 12587-12600 (2020). DOI: $10.1007 / \mathrm{s} 11356-020-07855-9$

This Article is brought to you for free and open access by the School of Chemical and Pharmaceutical Sciences at ARROW@TU Dublin. It has been accepted for inclusion in Articles by an authorized administrator of ARROW@TU

Dublin. For more information, please contact

arrow.admin@tudublin.ie, aisling.coyne@tudublin.ie, gerard.connolly@tudublin.ie.

Funder: Environmental Protection Agency (EPA)

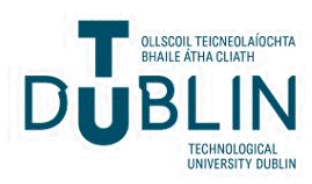




\section{Authors}

Connie O'Driscoll, Eoin McGillicuddy, Peter Croot, Pamela Bartley, John McMyler, Jerome Sheahan, and Liam Morrison 


\title{
Tracing sources of natural organic matter, trihalomethanes and metals in groundwater from a karst region
}

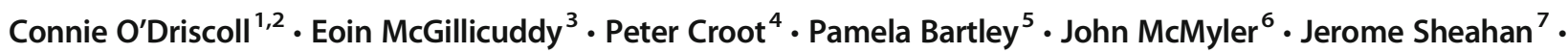 \\ Liam Morrison $^{8}$
}

Received: 2 June 2019 / Accepted: 23 January 2020 / Published online: 31 January 2020

(C) Springer-Verlag GmbH Germany, part of Springer Nature 2020

\begin{abstract}
Groundwater offers an important source for drinking water around the world; however, groundwater quality is under increasing pressure and is particularly vulnerable in karst areas. Total organic carbon (TOC) is significantly related to groundwater quality and when not removed by water treatment processes can give rise to the formation of disinfection by-products trihalomethanes (THMs) above the level of compliance. This study investigated the source of organic matter giving rise to the THM exceedances in a groundwater supply in a karst area. Results highlighted that source water for this groundwater supply was prone to surface water infiltration linked to rainfall events; was not accurately captured in the zone of contribution $(\mathrm{ZoC})$; had inadequate treatment of natural organic matter (NOM) and suffered THM exceedances in $45 \%$ of sampling events. THMs were mostly represented by chloroform and caused by terrestrial delivered reprocessed organic matter. This work will support water managers tasked with decision-making.
\end{abstract}

Keywords Trihalomethanes $\cdot$ Groundwater $\cdot$ Karst $\cdot$ Source protection zones $\cdot$ Drinking water $\cdot$ Granular activated carbon

\section{Introduction}

More than 2 billion people depend on groundwater for their daily water use $(75 \%, 51 \%$ and $25 \%$ of Europe, the USA and Ireland, respectively, McGrory et al. 2017, 2018), and in many parts of the world, groundwater bodies are considered the most important and safest sources of drinking water (Menichini et al. 2015). However, groundwater quality is under increasing pressure due to point and non-point source pollution (Pavlis and Cummins 2014a) and is particularly vulnerable in areas with underlying geology composed of carbonate rocks, i.e. karst areas. Human activity in karst regions threatens to contaminate groundwater resources far more easily than is the case for other aquifers types. Groundwater vulnerability, the likelihood of contaminants reaching the groundwater system after introduction at some location above the
Responsible editor: Philippe Garrigues

Electronic supplementary material The online version of this article (https://doi.org/10.1007/s11356-020-07855-9) contains supplementary material, which is available to authorized users.

Connie O’Driscoll

connieodriscoll@gmail.com

1 Department of Civil Engineering, Trinity College Dublin, Dublin, Ireland

2 Department of Civil Engineering, National University of Ireland Galway, Galway, Ireland

3 School of Chemical \& Pharmaceutical Sciences, Technological University Dublin City Campus, Kevin St., Dublin 8, Ireland
4 iCRAG (Irish Centre for Research in Applied Geoscience, Earth and Ocean Sciences, School of Natural Sciences and Ryan Institute, National University of Ireland Galway, Galway, Ireland

5 Hydro-G, 50 Henry St, Galway, Ireland

6 Galway Co. Council, Liosban Industrial Estate, Tuam Road, Galway, Ireland

7 School of Mathematics, Statistics and Applied Mathematics, National University of Ireland, Galway, Galway, Ireland

8 Earth and Ocean Sciences, School of Natural Sciences and Ryan Institute, National University of Ireland, Galway, Ireland 
aquifer through topsoil and subsoil or via surface karst features (e.g. dolines, swallow holes), cracks and fissures of bedrock, can be investigated by establishing hydrogeological conditions such as water transit time and dissolved elements (Pavlis and Cummins 2014a).

Presence of natural organic matter (NOM), for which total organic carbon (TOC) is a surrogate, in raw drinking water poses one of the greatest challenges for water treatment owing to the spectrum of problems associated with it (i.e. membrane fouling, coagulant dose, $\mathrm{pH}$ adjustments, higher disinfectant dose, energy consumption, transport of contaminants). NOM refers to a broad range of carbon-based compounds originating from living and dead plants, animals and microorganisms and from the degradation products of these sources (Chow et al. 1999). Understanding catchment processes including land use offers the potential to reduce 'end of pipe' treatment costs and will form part of the solution to addressing the problem of NOM (Brooks et al. 2015). TOC concentration is significantly related to groundwater vulnerability and land use is considered to be a driving factor of TOC concentration in groundwater (Pavlis and Cummins 2014a).

Both quantity and quality of NOM affect the efficiency of its removal, and so adequate information about concentration and composition is required at both the design and operation stage. Owing to the complexity of NOM characterisation, routine monitoring of NOM fractions poses a challenge. Fluorescence excitation-emission matrix (F-EEM) spectroscopy has been used to distinguish different types and sources of dissolved organic carbon (DOC) in natural waters and has gained popularity in recent years as a simple, relatively inexpensive yet sensitive approach (Baghoth et al. 2011). F-EEM spectroscopy has been used to characterise DOC and identify humic- and protein-like fluorescent signals in water samples from different aquatic environments (Coble 1996). F-EEMs coupled with PARAFAC (multiway data analysis using parallel factor analysis (Stedmon et al. 2003)) can provide even more detailed information about NOM character. PARAFAC has been employed successfully to track the fate of problematic NOM fractions and to optimize the design and operation of drinking water treatment processes for their removal (Shutova et al. 2014) as well as to infer DOC source (Kraus et al. 2010).

The delineation of catchment areas is crucial in terms of protecting groundwater drinking supplies. A zone of contribution $(\mathrm{ZoC})$ is the area surrounding a pumped well that encompasses all areas or features that supply groundwater recharge to the well. The determination of a rigorous and scientific methodology for all types of aquifer systems is very difficult in practicality (Menichini et al. 2015). Zone of contribution's (ZoCs) are commonly delineated as a 'rapid assessment' desk study using information on the groundwater recharge rates and groundwater flow direction (Irish EPA 2011a) which is then made available to water managers. Caveats are typically applied citing 'extent and geometry of the associated $\mathrm{ZoC}$ is highly uncertain due to the karstic nature of the limestone aquifer'. Alternatively, hydrochemical site-specific investigations coupled with statistical techniques have been successfully applied to reveal relationships among potential indicators of groundwater vulnerability, including principal components analysis (PCA) (Pavlis and Cummins 2014a).

The presence of NOM in groundwater can affect a number of geochemical processes including the transport and mobility of metal contaminants and their interaction (dissolution and precipitation reactions) with oxides and minerals (Redman et al. 2002; Weng et al. 2009). Metals in groundwater pose a potential threat to human health worldwide (Mitchell et al. 2011; Lipczynska-Kochany 2018). Furthermore, NOM gives rise to disinfection by-product formation (DBPs) when not adequately removed. DBPs are formed when natural water is disinfected to control microbial contaminants during the treatment of drinking water. DBPs may comprise halogenated and nonhalogenated compounds, depending on the nature of disinfectants used and precursors present (Krasner 2009). Trihalomethanes (THMs) are the most prominent class of halogenated DBPs in treated water (Krasner et al. 1989) and the only one regulated by European Union Drinking Water Regulations (EU 2014); albeit the proposed new Drinking Water Directive is set to include haloacetic acids (HAAs) (European Commission 2018).

THMs are used as a surrogate for DBPs in many countries but do not give a true representation of the extent of DBPs present in drinking water (Krasner 2009). It has been estimated that prominent identifiable DBPs only constitute $30 \%$ of the total organic halogens formed during chlorination ( $\mathrm{Li}$ and Mitch 2018). THMs have been shown to have both genotoxic and carcinogenic effects particularly in the liver and kidney in laboratory experimental studies (WHO 2011). Carcinogens differ from toxic compounds in that there is no threshold limit for the existence of risk. However, a parametric limit of $100 \mu \mathrm{g} \mathrm{L}^{-1}$ has been adopted in Europe and $80 \mu \mathrm{g} \mathrm{L}^{-1}$ in the USA. Ireland has the highest reported non-compliance for THM exceedances in drinking water across the 27 EU Member States (EC 2014), and in August 2018, the EC opened an infringement case against Ireland for failure to ensure drinking water for over 500,000 consumers is safe from THMs.

The high non-compliance has been attributed to high percentage cover of organic soils, a heavy reliance on surface water $(\sim 75 \%)$ coupled with a historical lack of understanding of NOM and treatability (O’Driscoll et al. 2018). In Ireland, half of the land area of the country is considered to be underlain by limestone, and the majority of this is considered karstified to some degree (Naughton et al. 2012). Therefore, the objectives of this study were to trace the sources of NOM and investigate the presence of THMs and priority metal pollutants in a drinking water supply abstracting water from a groundwater spring in a vulnerable karst region. 


\section{Materials and methods}

\section{Study site}

Williamstown Public Water Supply (WPWS) was chosen for this study as it represents a spring source located in a vulnerable karst area with a history of THM exceedances (Fig. 1). The ZoC for WPWS was previously mapped as part of a desk study and the catchment area estimated at $1.41 \mathrm{~km}^{2}$ (Irish EPA 2011b). However, the report highlighted that this source was part of a much larger spring system and several important karst features in the area, including turloughs and swallow holes, were excluded from the ZOC of the WPWS but acknowledged as important for the catchment area of the much larger spring system to the immediate west of WPWS source. In consideration of this potentially larger $\mathrm{ZoC}$, a greater area was considered as part of this study, and water samples were collected at five locations within a 4-km radius of WPWS spring (hereafter referred to as the catchment sites) and incorporating (1) a wetland, (2) a turlough, (3) a small tributary, (4) a series of sister springs (SisterSpring) adjacent to the raw water abstraction and (5) the outlet of a wastewater treatment plant (WWTP). Water samples were also collected from different points along the treatment process train of the WPWS and at eleven points along the distribution network (raw, post-ozone, post-granular activated carbon (GAC), before and after two reservoirs (Reservoir 1 and Reservoir 2, located at $1.8 \mathrm{~km}$ and $3.3 \mathrm{~km}$ from the treatment plant, respectively), a public water tap (located at $2.7 \mathrm{~km}$ from the treatment plant) and at four of the network extremities (NS8, NS9, NS10 and NS11 located at $6.7 \mathrm{~km}, 7.5 \mathrm{~km}, 7.7 \mathrm{~km}$ and $8.1 \mathrm{~km}$ from the treatment plant, respectively) (Fig. 1). The treatment train at WPWS consists of ozonation, GAC filtration (CARBSORB $®$ ) and UV disinfection followed by chlorinebased final disinfection. WPWS supplies $558 \mathrm{~m}^{3} \mathrm{~d}^{-1}$ to a population of approximately 180 persons.

\section{Water quantity and quality}

In order to estimate a potential $\mathrm{ZoC}$, a staff gauge was installed at the SisterSpring (01/12/2014). A rating curve was developed using spot flow measurements at a range of flows which established that while the WPWS spring had a daily discharge of $\sim 600 \mathrm{~m}^{3} \mathrm{~d}^{-1}$, the adjacent SisterSpring had a daily discharge of $\sim 19,000 \mathrm{~m}^{3} \mathrm{~d}^{-1}$. Using topography, known tracers and the integration of recharge coefficients, a reasonable and justifiable catchment size for the combined WPWS spring and SisterSpring was estimated to be $\sim 24 \mathrm{~km}^{2}, 16$-fold greater than the ZoC report for the WPWS (Irish EPA 2011b). Monthly water samples (08/2014-04/2016; 16 sampling occasions) were collected at each of the 17 sampling locations. Water samples were collected in pre-labelled, sterilized, polypropylene bottles and kept cold in the dark during transport to the laboratory, where they were analysed within $72 \mathrm{~h}$.

Each water sample was analysed for coloured dissolved organic matter (CDOM) fluorescence, ultraviolet absorbance $\left(\mathrm{UVA}_{254}\right)$ and DOC analysis as follows: DOC and TN concentrations were determined using a TOC Analyser (BioTector Analytical Systems Ltd., Cork, Ireland). UV absorption data was obtained with a UV-visible spectrophotometer (Cary 50, Agilent Technologies), using a quartz sample cell with a path length of $10 \mathrm{~mm}$. Fluorescence excitation emission matrices (EEMs) were obtained using a 1-cm path length quartz cuvette

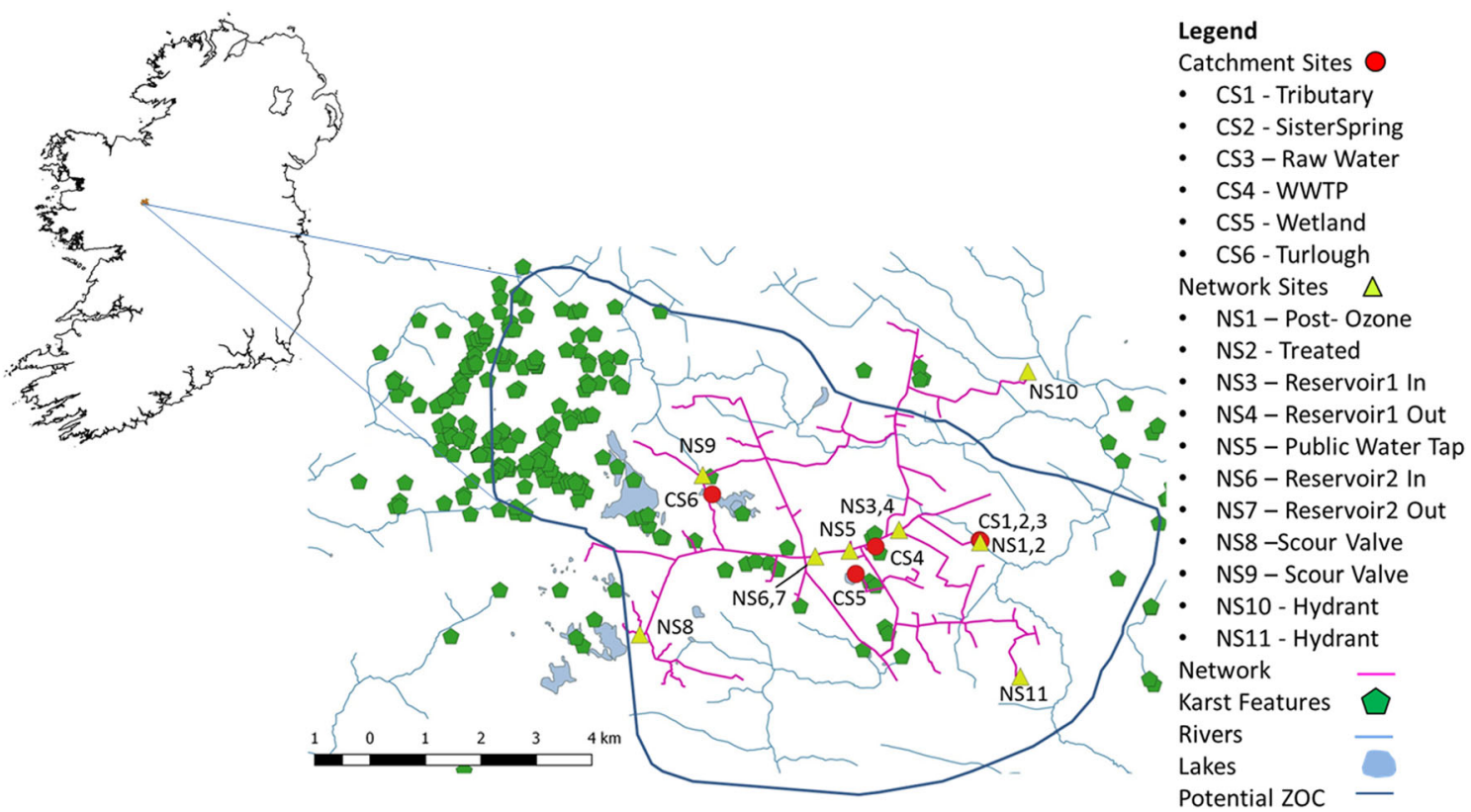

Fig. 1 Geographical location of the study site in Ireland (left) and of the 17 sampling sites in the potential zone of contribution and along the water supply distribution network 
(Starna, Australia) on a Horiba Aqualog (Kyoto, Japan). A 0.1-s integration time was used during measurement of emission from 200 to $625 \mathrm{~nm}$ and excitation from 240 to $600 \mathrm{~nm}$. Chargecoupled device (CCD) gain, i.e. the conversion between the number of electrons recorded by the $\mathrm{CCD}$ and the number of digital units contained in the CCD image, was set to medium. Inner filter effects and first- and second-order Rayleigh scattering were removed using the included Aqualog (v3.6.10) software. The area of the Raman peak ( $350 \mathrm{~nm}$ excitation) was used to normalize the fluorescence intensity of all spectra, which are expressed in Raman units (RU) (Lawaetz and Stedmon 2009; Murphy et al. 2010). The slope ratio or SR was calculated as the ratio of S275-295 to S350-400. The E2/E3 ratios were calculated using absorption coefficients at the appropriate wavelengths. SUVA 254 , defined as the UV absorbance of a water sample at a given wavelength normalized for DOC concentration, was calculated by dividing $a_{254}\left(\mathrm{~m}^{-1}\right)$ by the DOC concentration $\left(\mathrm{mg} \mathrm{L}^{-1}\right)$ as in Weishaar et al. (2003).

In addition, water samples were collected for the determination of metals from the catchment sites ( $n=6$, including raw water) and at the post-ozone and treated water sites $(n=8)$, filtered $(0.45 \mu \mathrm{m}$ sterile syringe filter, Sarstedt Ltd.), acidified to $1 \%$ using nitric acid $\left(\mathrm{HNO}_{3}\right)$ (ROMIL UpA ${ }^{\mathrm{TM}}$ Nitric Acid) and stored in trace metal-free, polyethylene bottles for the determination of the following elements (magnesium $(\mathrm{Mg})$, silica $(\mathrm{Si})$, calcium $(\mathrm{Ca})$, sodium $(\mathrm{Na})$, strontium $(\mathrm{Sr})$, potassium $(\mathrm{K})$, chromium $(\mathrm{Cr})$, iron $(\mathrm{Fe})$, zinc $(\mathrm{Zn})$, selenium $(\mathrm{Se})$ ) and trace elements (aluminium (Al), arsenic (As), boron (B), barium $(\mathrm{Ba})$, cadmium $(\mathrm{Cd})$, cobalt $(\mathrm{Co})$, copper $(\mathrm{Cu})$, manganese $(\mathrm{Mn})$, molybdenum (Mo), nickel $(\mathrm{Ni})$, lead $(\mathrm{Pb})$, titanium (Ti), vanadium (V)). Analyses were performed using inductively coupled plasma mass spectrometry (ICP-MS) (PerkinElmer ELAN DRCe, Waltham, USA) (Li et al. 2013; Brennan et al. 2017; Pathak et al. 2017; Peyton et al. 2017) in a class 1000 (ISO class 6) cleanroom at the Chemical Monitoring Facility at NUI, Galway.
Furthermore, water samples were taken for THM analysis at six locations, immediately after treatment (NS2), at the public water tap (NS5) and at each of the network extremities (NS8, NS9, NS10, NS11 (Fig. 1)). Samples were taken in glass vials (prepared with sodium thiosulfate and septa lids) and were sent to an external accredited laboratory (CLS Connemara, Galway, Ireland) for analysis of THMs (chloroform, bromoform, dibromochloromethane and bromodichloromethane).

Analysis of the fluorescence EEMs was carried out using the drEEM toolbox (Murphy et al. 2013) for MATLAB (MathWorks) for implementing parallel factors analysis (PARAFAC). The methodology presented by Murphy et al. (2013) was followed to determine an adequate PARAFAC model. The processed data (blank subtraction, Rayleigh and Raman scatter regions removed, Raman normalization and IFE corrections) was imported into MATLAB. Regions were smoothed using the drEEM interpolation functions. The fluorescence signals were then normalized to reduce the leverage of extreme values for the purposes of developing a PARAFAC model, and the normalization processes were reversed after validation. To establish a robust PARAFAC model, several samples were identified as outliers through observation of sample leverages on the model. The validity of the PARAFAC model was established through several ways. Spectral loadings of the components were observed to conform to general guidelines of how organic fluorophores signals appear (e.g. only one emission peak, no abrupt changes in loadings with wavelength). Residuals calculated as the difference between the modelled and measured spectra were generally random with few minor peaks. Split-half validation was also carried out based on a randomized split of the dataset into 6 equal parts to form 3 unique comparisons of dataset halves. For each unique half (combination of two splits), an independent PARAFAC model was developed, and the components were found to be identical for all combinations as well as to the overall model. Finally, comparison of the resulting PARAFAC components with the OpenFluor database
Fig. 2 Monthly total precipitation on the $y$-axis recorded at the Met Éireann weather station (circa $12 \mathrm{~km}$ south of the study site) and average monthly temperature on the $\mathrm{z}$-axis

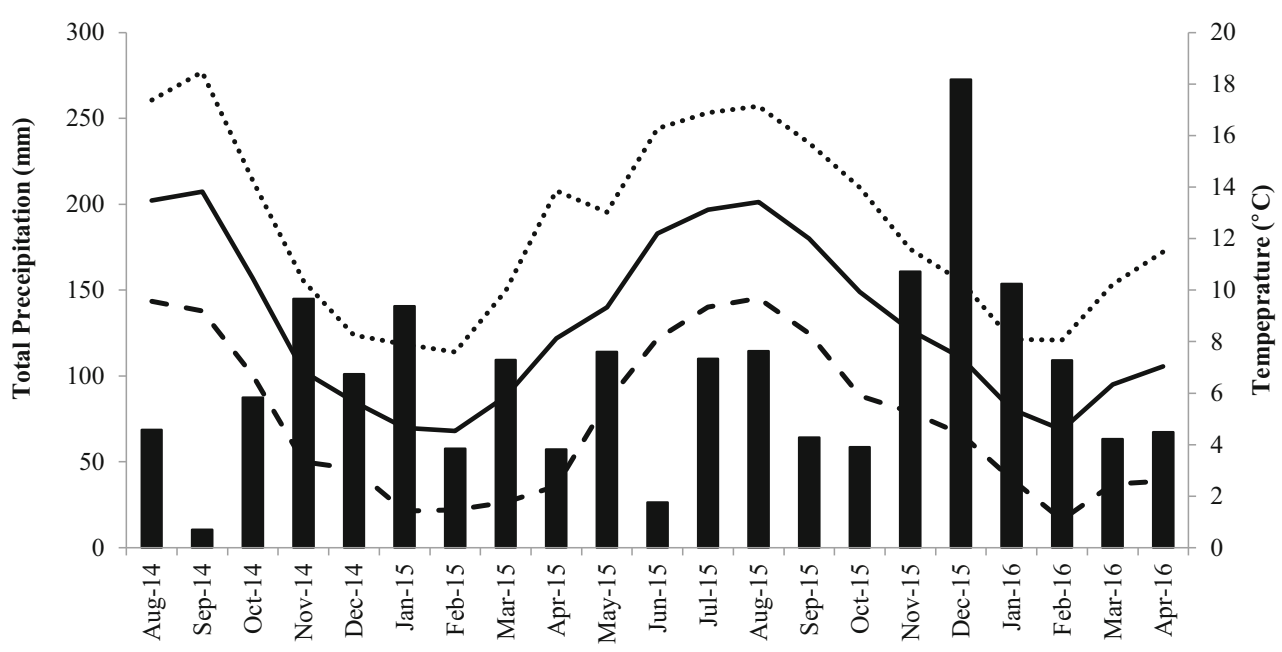


Fig. 3 Mean estimated stream discharge $\left(\mathrm{m}^{3} \mathrm{~d}^{-1}\right)$, from the SisterSpring over the observation period (12/11/2014-22/07/2015), with corresponding daily total precipitation $(\mathrm{mm})$

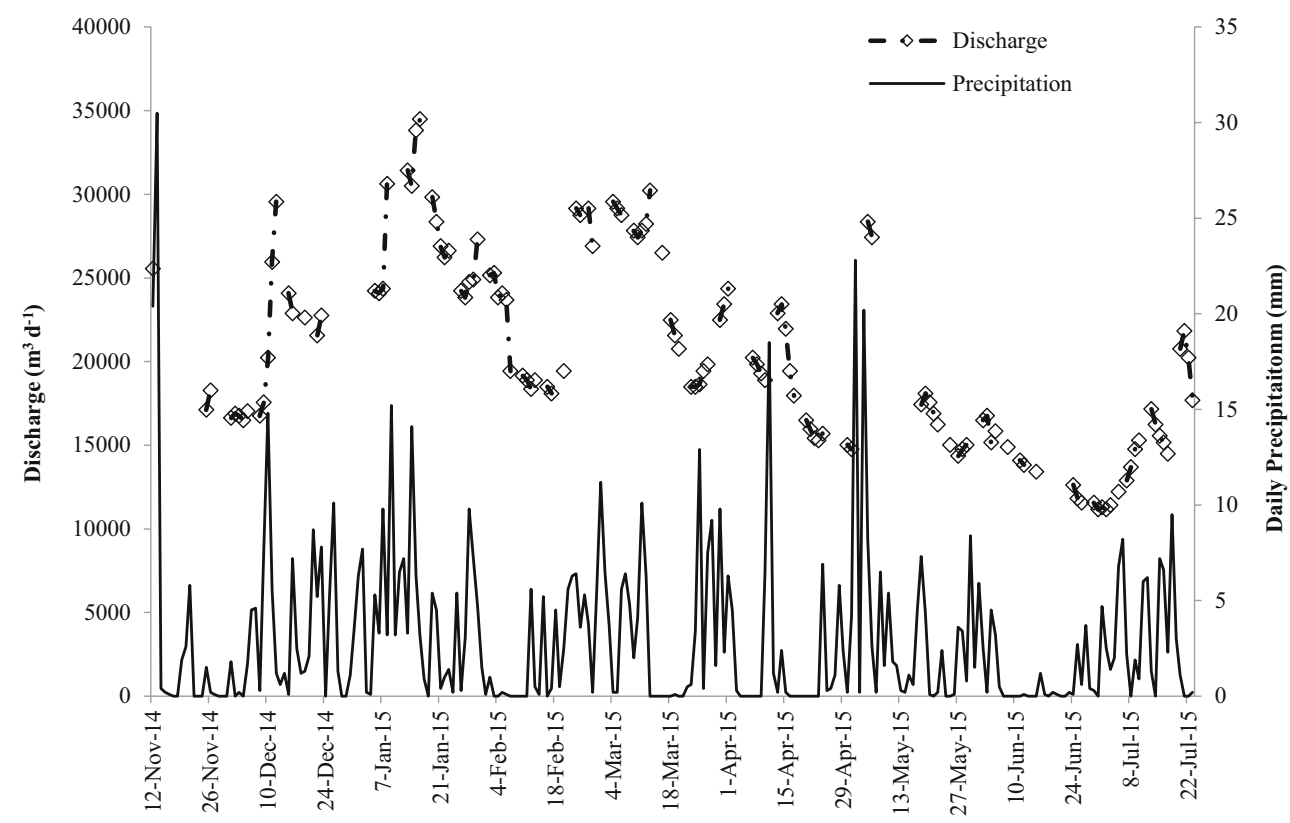

(Murphy et al. 2014) also provide some indication of model validity. After reversal of the fluorescence normalization, results from the model were reported as Fmax values in RU.

\section{Principal component analysis}

PCA was used to investigate the relationships between the hydrochemical indicators in the database. PCA is a method of data reduction. It attempts to replace the original variables (typically standardized, see Reimann et al. 2008) by a smaller set of principal components (PCs), each of which is a linear combination of the original variables. These PCs are constructed to have decreasing variance, to be mutually orthogonal and to be such that the sum of their variances is equal to the sum of the variances of the original variables. The sample PCs extracted are estimates of the corresponding population PCs. The relationship of the variables with a given direction of maximum variance (i.e. a principal component) can be visualized with a biplot. The length of the arrows represents the variability explained in two principal components, and the angle between two arrays indicates their correlation (Reimann et al. 2008). Principal component analysis was conducted with IBM SPSS 22.0 (IBM Corp 2013), and graphical representation was performed using CANOCO version 4.1 (ter Braak and Šmilauer 1998).

\section{Results and discussion}

\section{Catchment sites water quality and quantity}

Mean air temperature (Met Éireann) was $8.7{ }^{\circ} \mathrm{C}$ during the study period (1.08-18.5 ${ }^{\circ} \mathrm{C}$, daily minimum and maximum, respectively). Average monthly precipitation was $100 \mathrm{~mm}$ with two extremely dry months observed (09/2014 and 06/ 2015) and one extremely wet month (12/2015) (Fig. 2).

Mean estimated stream discharge from the SisterSpring over the observation period (12/11/2014-22/07/2015) was
Fig. 4 Dissolved organic carbon concentrations from water samples taken at the WPWS raw water abstraction and following ozonation and granular activated carbon filtration

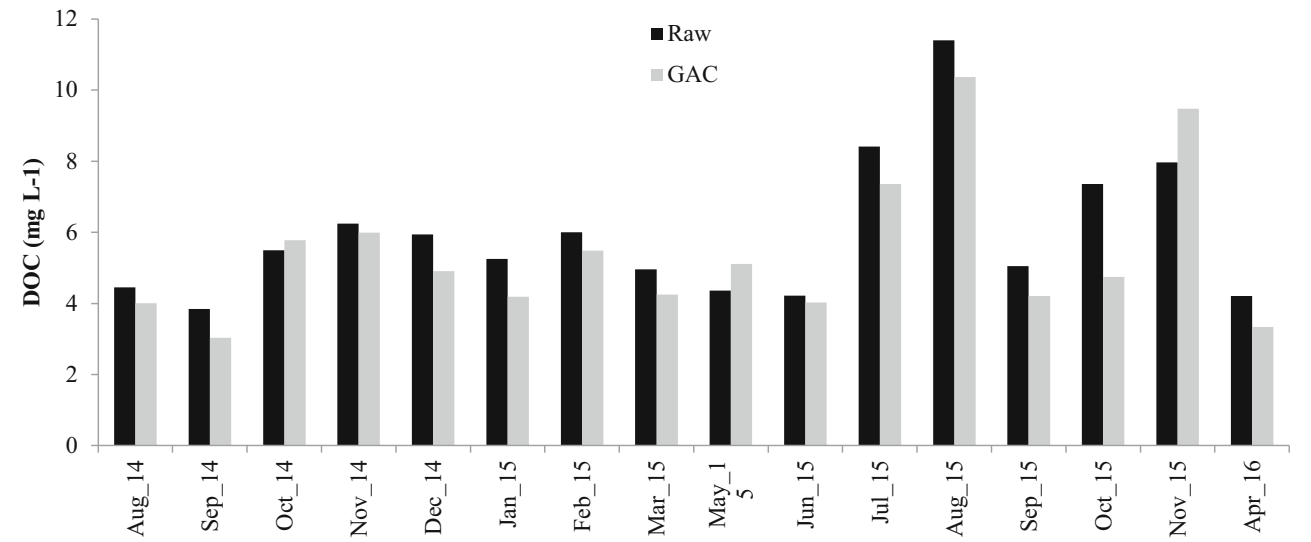




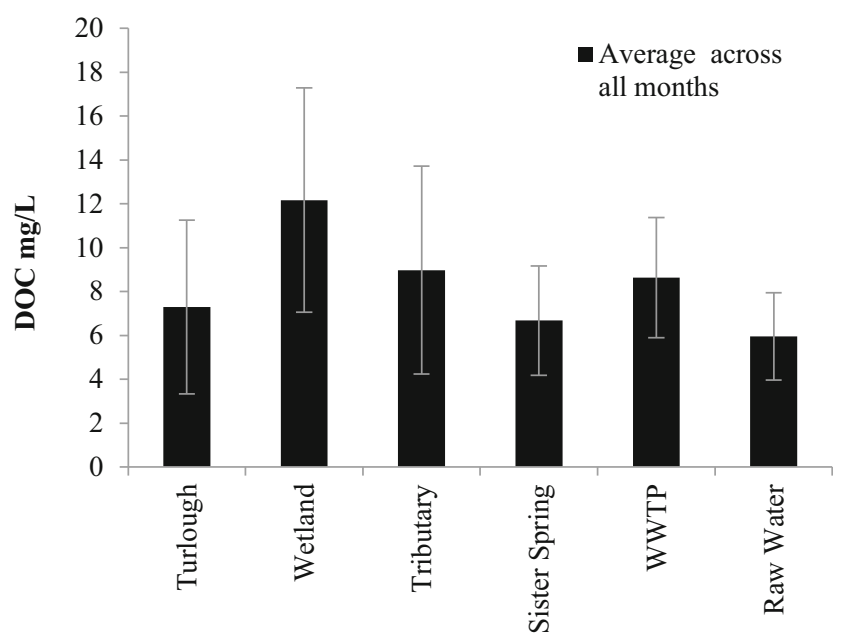

Fig. 5 Dissolved organic carbon concentrations from the five locations in a $4-\mathrm{km}^{2}$ vicinity of the WPWS spring and the WPWS spring/raw water over the duration of the study period. Error bars highlight the standard deviation

$20,559 \mathrm{~m}^{3} \mathrm{~d}^{-1}\left(11,163 \mathrm{~m}^{3} \mathrm{~d}^{-1}, 34,497 \mathrm{~m}^{3} \mathrm{~d}^{-1}\right.$ minimum and maximum, respectively, Fig. 3). Maximum change in recorded water level over the observation period was $\sim 100 \mathrm{~mm}$ throughout the winter and $50 \mathrm{~mm}$ through the summer. Instantaneous discharge response to rainfall peaks suggests that there is no major storage deep in the groundwater/ bedrock system. DOC concentrations from the WPWS Raw water varied $\left(3.84-11.40 \mathrm{mg} \mathrm{L}^{-1}\right)$ with an average of $5.95 \mathrm{mg} \mathrm{L}^{-1}$ (Fig. 4). An overall seasonal trend could be observed with DOC concentrations increasing by $2 \mathrm{mg} \mathrm{L}^{-1}$ from summer to winter with the exception of July and August 2015. The highest DOC concentrations were observed in July and August 2015 following the drought period in June 2015. DOC concentrations plotted against temperature showed no correlation. DOC concentrations displayed a strong positive correlation with precipitation $\left(R^{2}=0.7611, \rho<0.001\right)$.

DOC concentrations from the catchment sites varied with the wetland site showing the highest concentrations (20.46 $\left.\mathrm{mg} \mathrm{L}^{-1}, 09 / 2015\right)$ and the WPWS raw water site, the lowest (Fig. 5). DOC concentrations observed in the raw water were indicative of groundwater strongly influenced by the occurrence of surface karst features (Pronk et al. 2006). In comparison to other catchment sites, the adjacent SisterSpring and the Turlough site $\sim 4 \mathrm{~km}$ away had the most similar mean DOC concentrations to the raw water. In lowland karst regions, underground water flow occurs through the epikarst and consequently discharges to springs, turloughs and streams, and as a result, surface and underground flow systems are highly connected (Pavlis and Cummins 2014b). Seasonal variation was evident; however, response to high rainfall events overrides the seasonality as can be observed in July and August 2015 (Fig. 4; Kraus et al. 2010). Temporal variation was more evident at the surface water sites, demonstrated by the high standard deviations at the wetland and tributary sites (Fig. 5).

All concentrations of major cations and trace elements in the water samples were lower than the permissible limits of the EU Drinking Water Regulations (EU 2014). PCA ordination results showed that $62.4 \%$ of water chemistry variance was explained $(21.4 \%$ on axis 1 , with a further $17.4 \%$ explained on axis $2,13.8 \%$ on axis 3 and $9.8 \%$ on axis 4 ) (Fig. 6). There are three main groupings of samples, the first at the top of the graph (dominated by Wetland samples), the second on the left hand side (dominated by Raw water, Turlough and Sister Spring samples) and the third on the right hand side of the graph (dominated by the WWTP samples). As can be seen by the PCA biplot, the first principal component (x-axis) is determined by DOC, Ba, Mn and Mo. DOC,
Fig. 6 Biplot of the hydrochemical data produced with principal components analysis

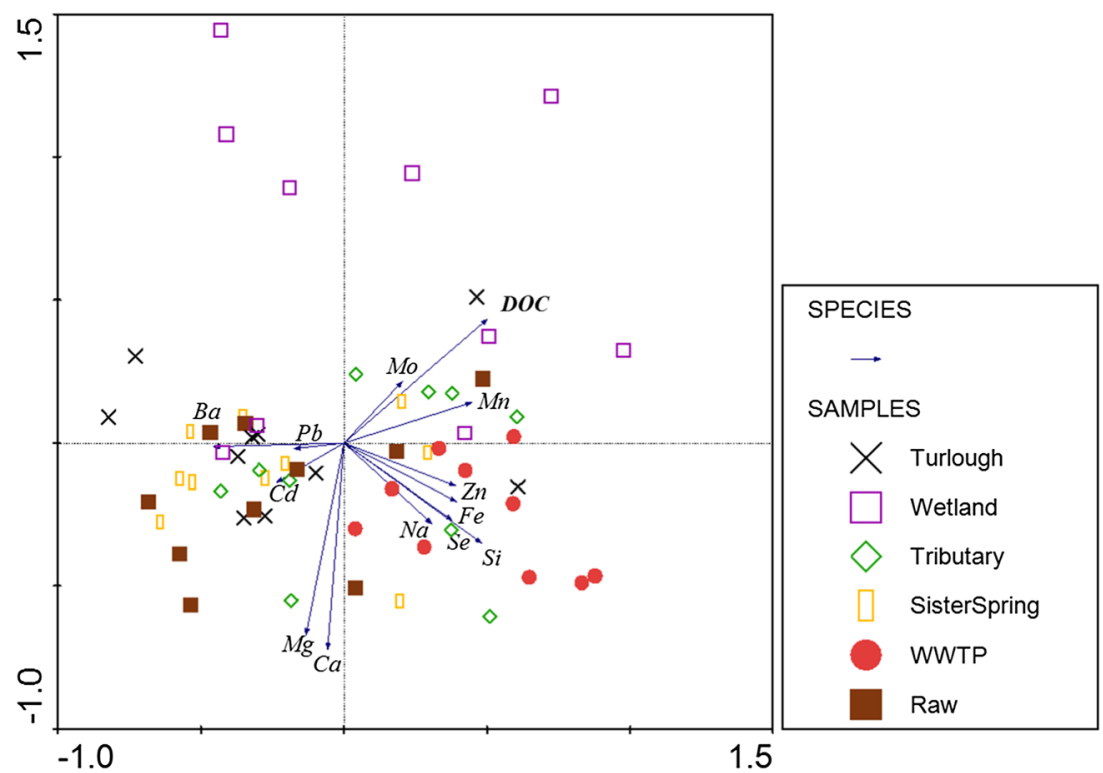


Table 1 Average concentrations of nutrients and metals analysed during the study ( $n=10$; standard deviations are denoted by italics)

Turlough Wetland Tributary SisterSpring WWTP Raw

\begin{tabular}{|c|c|c|c|c|c|c|c|c|c|c|c|c|c|}
\hline & & & & & & & $\mathrm{Sb}^{* * *}$ & 0.05 & 0.06 & 0.05 & 0.05 & 0.21 & 0.04 \\
\hline \multirow[t]{2}{*}{ DIC* } & 48.28 & 38.89 & 70.20 & 66.21 & 59.19 & 65.64 & & 0.05 & 0.07 & 0.05 & 0.05 & 0.18 & 0.04 \\
\hline & 7.16 & 15.17 & 13.92 & 7.09 & 8.97 & 7.49 & $\mathbf{S e}^{* *}$ & 0.03 & 0.02 & 0.01 & 0.01 & 0.01 & 0.01 \\
\hline \multirow[t]{2}{*}{ DOC* } & 7.03 & 13.38 & 9.68 & 6.89 & 8.92 & 6.39 & & 0.03 & 0.02 & 0.01 & 0.01 & 0.01 & 0.01 \\
\hline & 3.64 & 5.37 & 5.17 & 2.76 & 3.17 & 2.36 & $\mathrm{Sn}^{* * *}$ & 1.02 & 0.86 & 0.71 & 0.58 & 0.67 & 0.53 \\
\hline \multirow[t]{2}{*}{$\mathbf{T N}^{*}$} & 0.78 & 0.79 & 1.37 & 1.35 & 4.49 & 1.79 & & 2.23 & 1.82 & 1.50 & 1.22 & 1.15 & 1.02 \\
\hline & 0.43 & 0.46 & 0.25 & 0.40 & 1.41 & 0.37 & $\mathbf{T i}^{* *}$ & 0.48 & 0.63 & 0.72 & 0.50 & 6.08 & 0.52 \\
\hline \multirow[t]{2}{*}{$\mathbf{U V A}_{254}$} & 0.14 & 0.42 & 0.37 & 0.23 & 0.20 & 0.22 & & 0.27 & 0.40 & 0.45 & 0.28 & 3.66 & 0.28 \\
\hline & 0.03 & 0.15 & 0.27 & 0.11 & 0.07 & 0.12 & $\mathbf{V}^{* * *}$ & 0.31 & 0.40 & 0.66 & 0.36 & 0.58 & 0.36 \\
\hline \multirow[t]{2}{*}{$\mathbf{C a}^{*}$} & 85.58 & 68.01 & 116.56 & 103.16 & 96.52 & 102.95 & & 0.37 & 0.55 & 0.42 & 0.30 & 0.37 & 0.25 \\
\hline & 15.06 & 23.13 & 19.57 & 10.07 & 12.13 & 9.52 & $\mathbf{Z n}^{* *}$ & 11.80 & 15.23 & 7.71 & 6.30 & 48.30 & 11.90 \\
\hline \multirow[t]{2}{*}{$\mathbf{K}^{*}$} & 2.00 & 4.07 & 2.83 & 2.40 & 9.76 & 2.42 & & 9.36 & 11.65 & 5.31 & 3.44 & 27.49 & 6.59 \\
\hline & $\begin{array}{l}0.43 \\
6.76\end{array}$ & $\begin{array}{l}3.54 \\
3.99\end{array}$ & $\begin{array}{l}0.44 \\
5.04\end{array}$ & $\begin{array}{l}0.27 \\
6.08\end{array}$ & $\begin{array}{l}3.46 \\
5.56\end{array}$ & $\begin{array}{l}0.22 \\
6.28\end{array}$ & & & & & & & \\
\hline
\end{tabular}

$\begin{array}{rrrrrrr} & 1.11 & 1.62 & 1.07 & 1.13 & 1.05 & 1.53 \\ \mathbf{N a}^{*} & 8.32 & 9.80 & 10.07 & 8.91 & 39.88 & 9.98 \\ & 1.12 & 2.69 & 1.54 & 1.20 & 9.95 & 3.28\end{array}$

\begin{tabular}{|c|c|c|c|c|c|}
\hline & 1.12 & 2.69 & 1.54 & 1.20 & 9.95 \\
\hline $\mathbf{S i}^{*}$ & 1.58 & 1.92 & 1.90 & 1.73 & 2.62 \\
\hline
\end{tabular}

$\begin{array}{lllllll} & 0.84 & 1.35 & 0.60 & 0.45 & 0.55 & 0.42 \\ \text { Sr* } & 0.35 & 0.44 & 0.44 & 0.40 & 0.51 & 0.40\end{array}$

$\begin{array}{rrrrrrr} & 0.46 & 0.71 & 0.74 & 0.65 & 0.84 & 0.66 \\ \mathbf{A} \mathbf{I}^{* *} & 6.11 & 8.74 & 20.10 & 7.29 & 8.86 & 8.71\end{array}$

$\begin{array}{rrrrrrr} & 3.78 & 3.40 & 15.76 & 4.95 & 3.52 & 6.13 \\ \text { As** }^{*} & 0.61 & 0.60 & 0.85 & 0.69 & 0.97 & 0.72 \\ & 0.33 & 0.17 & 0.33 & 0.10 & 0.21 & 0.09 \\ \text { B** } & 10.16 & 9.78 & 12.14 & 11.42 & 25.14 & 11.52 \\ & 2.09 & 1.44 & 1.91 & 1.57 & 4.55 & 1.76\end{array}$

$\begin{array}{rrrrrrr}\text { Ba** }^{*} & 11.49 & 9.03 & 9.03 & 9.75 & 6.89 & 9.62\end{array}$

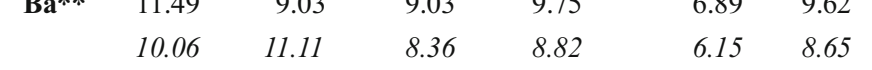

$\begin{array}{lllllll}\mathbf{C d}^{* *} & 0.04 & 0.03 & 0.04 & 0.03 & 0.03 & 0.04\end{array}$

$\begin{array}{llllll}0.03 & 0.02 & 0.03 & 0.02 & 0.03 & 0.04\end{array}$

$\begin{array}{lllllll}\text { Co }^{* *} & 0.18 & 0.18 & 0.29 & 0.19 & 0.26 & 0.20\end{array}$

$\begin{array}{llllll}0.04 & 0.08 & 0.04 & 0.02 & 0.06 & 0.06\end{array}$

$\begin{array}{lllllll}\mathbf{C r}^{* * *} & 0.14 & 0.28 & 0.40 & 0.27 & 0.22 & 0.49\end{array}$

$\begin{array}{lllllll} & 0.10 & 0.22 & 0.21 & 0.14 & 0.07 & 0.64 \\ \mathbf{C u} \mathbf{u}^{* *} & 0.99 & 1.71 & 1.14 & 1.21 & 3.16 & 1.98\end{array}$

$\begin{array}{llllll}0.44 & 0.72 & 0.38 & 1.26 & 1.77 & 0.56\end{array}$

$\begin{array}{lllllll}\mathbf{F e}^{* *} & 59.05 & 45.69 & 159.77 & 71.48 & 108.67 & 71.30\end{array}$

$\begin{array}{lrrrrrr} & 41.71 & 31.86 & 107.60 & 44.09 & 63.18 & 39.63 \\ \mathbf{M n * *} & 41.65 & 89.22 & 33.59 & 10.12 & 48.04 & 6.67 \\ & 51.60 & 78.01 & 18.25 & 6.50 & 31.24 & 3.68 \\ \mathbf{M o}^{* *} & 0.48 & 0.96 & 0.71 & 0.72 & 0.95 & 1.06 \\ & 0.85 & 2.25 & 1.62 & 1.61 & 2.21 & 2.09 \\ \mathbf{N b}^{* *} & 0.03 & 0.08 & 0.06 & 0.04 & 0.09 & 0.04 \\ & 0.04 & 0.13 & 0.09 & 0.06 & 0.16 & 0.07 \\ \mathbf{N i}^{* *} & 3.58 & 3.34 & 4.92 & 4.42 & 4.07 & 4.39 \\ & 0.73 & 1.19 & 0.52 & 0.69 & 0.56 & 0.66 \\ \mathbf{P b}^{* *} & 0.07 & 0.08 & 0.08 & 0.11 & 0.11 & 0.16 \\ & 0.04 & 0.07 & 0.07 & 0.14 & 0.09 & 0.26\end{array}$

Table 1 (continued)

Turlough Wetland Tributary SisterSpring WWTP Raw

considered to be of external origin, is introduced into the aquifer system via infiltration from the surface and is related to water transit time (Pavlis and Cummins 2014a). On the other hand, the second principal component axis (y-axis) is determined by $\mathrm{Ca}$ and $\mathrm{Mg}$, considered to be of internal origin (bedrock dissolution), and by elements related to anthropogenic pollution such as $\mathrm{Na}$, and Se that mostly have external origin (Pavlis and Cummins 2014a), however, may also be of natural origin. The raw water samples were most similar to the SisterSpring and Turlough sites except for three occasions following high rainfall when all sites became quite similar as the water table rose and lands became flooded (Table 1).

A four component model (C1-C4) was established based on several diagnostic criteria and random split validation (Fig. 7). Derived fluorescing components were crossreferenced with the OpenFluor database (Murphy et al. 2014), which provided context for the similarities between these organic fluorophores to those reported globally from other studies. A total of 42 studies were found with at least one of the three derived components with a high similarity score ( $>0.95$ ) (Table 2). The top 5 highest similarity scores are shown where available. According to previous classifications, $\mathrm{C} 1$ consisted of humic-like terrestrial organic matter, ubiquitous to freshwater, composed of high molecular weight and aromatic organic compounds; $\mathrm{C} 2$ consisted of humic-like, terrestrial-delivered reprocessed organic matter; $\mathrm{C} 3$ consisted of humic like terrestrial-derived organic matter; and $\mathrm{C} 4$ consisted of protein-like microbial-delivered organic matter. All four components are commonly reported in surface and treated water elsewhere (Shutova et al. 2014).

In all water samples taken from the catchment sites, $\mathrm{C} 1$ and $\mathrm{C} 2$ had higher fluorescence intensities than $\mathrm{C} 3$ and $\mathrm{C} 4$ (Fig. 8). All sites exhibited contrasting organic matter properties. Specifically, the Turlough and SisterSpring samples experienced the highest variability of $\mathrm{C} 1$ and $\mathrm{C} 2(0.99 \pm$ 


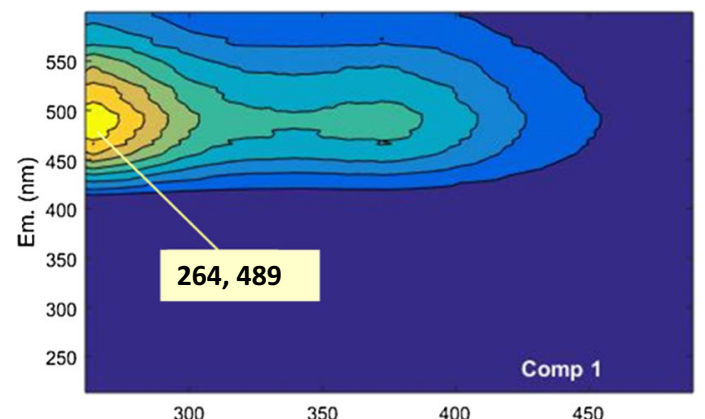

350

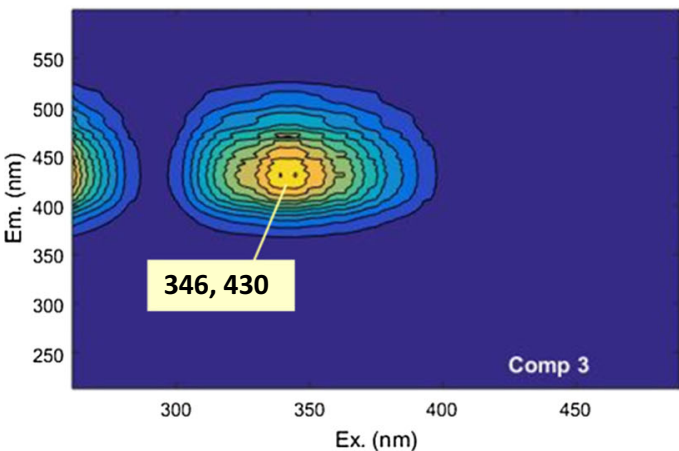

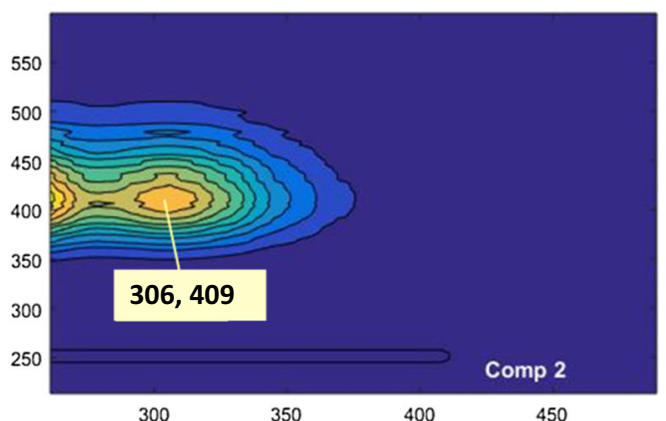

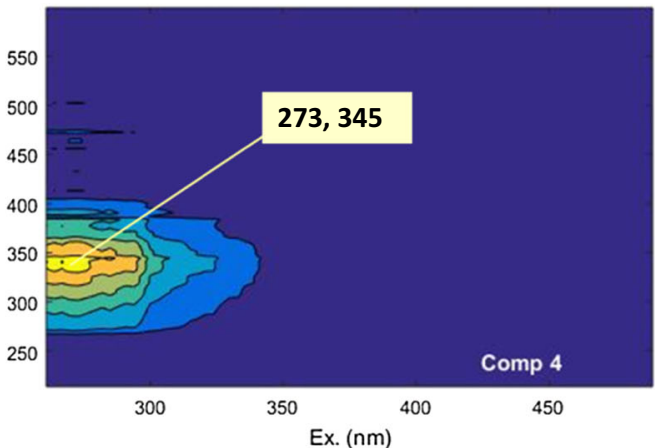

Fig. 7 Loading values for the 3 PARAFAC components with excitation $(\mathrm{nm})$ on the $\mathrm{x}$-axis and emission (nm) on the $\mathrm{y}$-axis

$0.28 \mathrm{RU}$ and $0.97 \pm 0.19 \mathrm{RU}$, respectively) in contrast to the raw water samples which tended to be stable for all components (Fig. 8). The two surface water fed sources (i.e. the wetland and the tributary) had greater median values of $\mathrm{C} 1$ and less of $\mathrm{C} 2$ compared with the four groundwater sampling locations which had similar medians for $\mathrm{C} 1$ and $\mathrm{C} 2$ (Fig. 8) highlighting a lengthier residence time of the water and perhaps prone to increased processing of OM. The WWTP has the highest range of fluorescence intensities for $\mathrm{C} 4$. C4 is associated with sewage-derived material presumably due to the production of NOM from microbial activity (Kraus et al. 2010). The WWTP included in this study is a constructed wetland, and catchment drainage is via a series of small streams that disappear underground via a swallow hole located
Table 2 Identities and related references for similar components using the OpenFluor database

\begin{tabular}{llll}
\hline Component & Similarity score* & Component identity & References \\
\hline C1 & 1.00 & Humic-like terrestrial-delivered OM & Shutova et al. 2014 \\
& 0.99 & Terrestrial humic-like OM & Walker et al. 2009 \\
& 0.99 & Humic-like fluorescence & Catala et al. 2015 \\
& 0.99 & Humic-like fluorescence & Murphy et al. 2006 \\
& 0.98 & Terrestrial humic-like & Lambert et al. 2016 \\
C2 & 0.99 & Humic-like, terrestrial-delivered reprocessed OM & Shutova et al. 2014 \\
& 0.99 & Terrestrial humic-like & Stedmon et al. 2007 \\
& 0.99 & Terrestrial humic-like & Lambert et al. 2016 \\
& 0.98 & Terrestrial humic-like & Cawley et al. 2012 \\
& 0.98 & Terrestrial humic-like & Williams et al. 2013 \\
C3 & 0.95 & Humic-like terrestrial delivered OM & Shutova et al. 2014 \\
C4 & 0.97 & Protein-like microbial delivered & Shutova et al. 2014 \\
& 0.96 & Protein-like microbial delivered & Walker et al. 2013 \\
& 0.96 & Protein-like & Cawley et al. 2012 \\
& 0.96 & Autochthonous DOM & Kowalczuk et al. 2009 \\
& 0.96 & Protein-like & Williams et al. 2013 \\
\hline
\end{tabular}


Fig. $8 \mathrm{~F}_{\max }$ of fluorescence components at the catchment sites

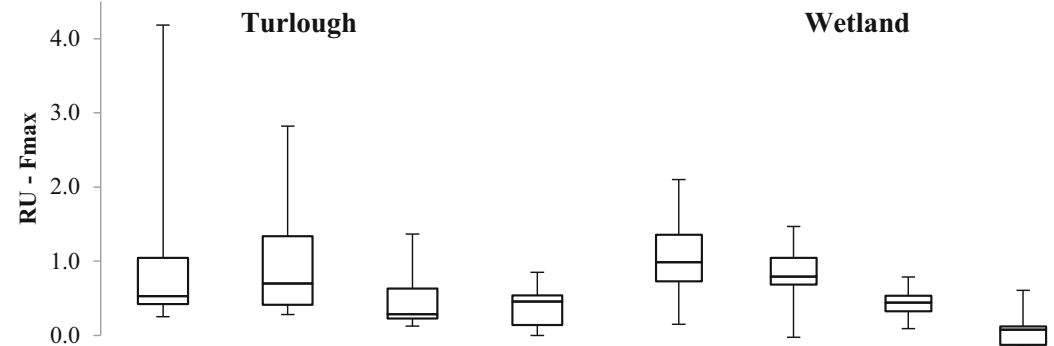

\section{SisterSpring}
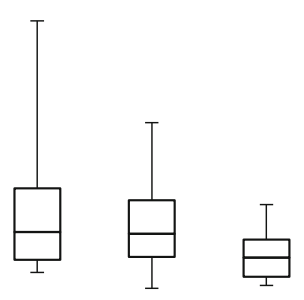
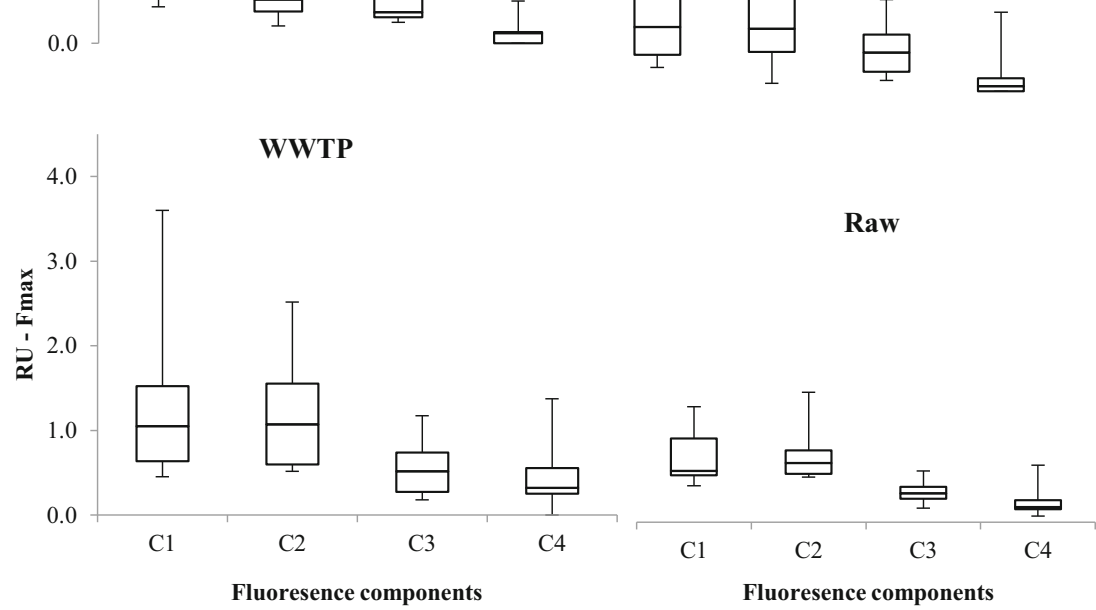

approximately $500 \mathrm{~m}$ east of the site. Lower efficiencies at the WWTP during the summer periods have been reported owing to the formation of algal blooms in the detention pond (Healy and Cawley 2002).

The ZoC delineated in the desktop study did not accurately capture relevant catchment information pertaining to this supply. The application of Geographical Information Systems (GISs) in the risk assessment of drinking water for the purposes of implementing water safety plans is dependent on accurate catchment boundaries. ZoCs have recently been distinguished separate to Source Protection Areas (SPAs) and Source Protection Zones (SPZs) which have a higher degree
Fig. $9 \mathrm{UVA}_{254}$ measured at the raw water, post-ozone and postGAC sampling points

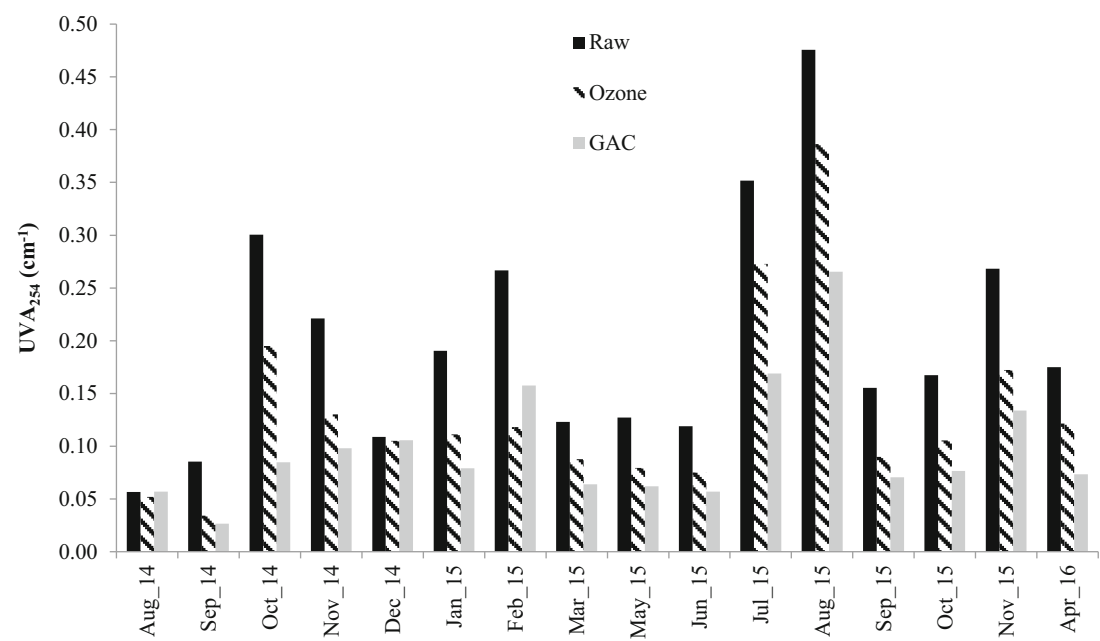


Fig. $10 \mathrm{~F}_{\max }$ concentrations for Compoents C1, C2, C3 and $\mathrm{C} 4$ from the raw, ozone and $\mathrm{GAC}$ sampling points

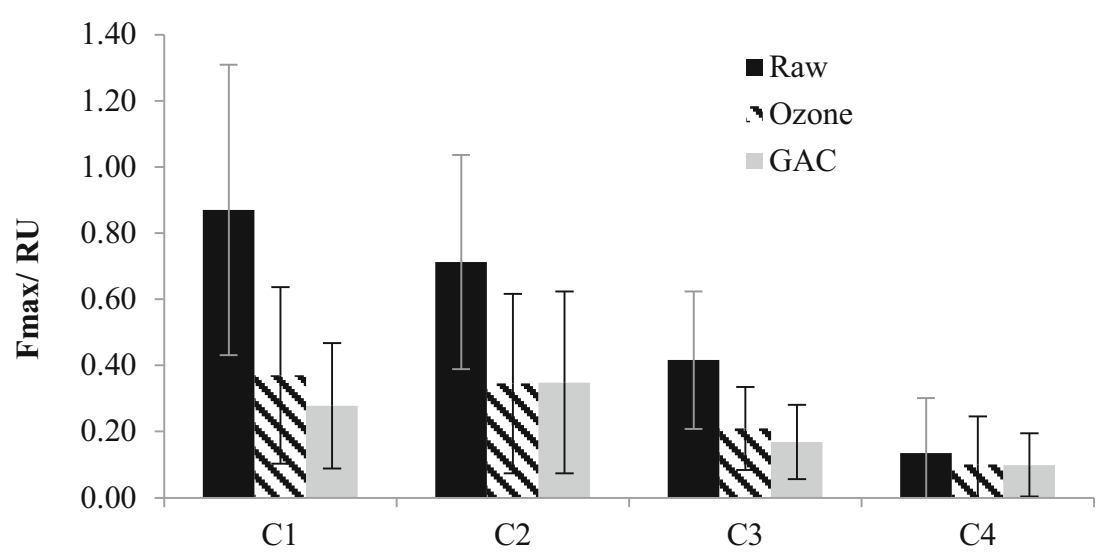

of certainty associated with them for protection of groundwater sources (Hunter Williams et al. 2017).

\section{Treatment}

Raw and treated water DOC concentrations had similar concentrations suggesting limited removal of NOM. The average DOC concentration in water samples taken after the GAC filter was $5.39 \mathrm{mg} \mathrm{L}^{-1}\left(3.30-10.37 \mathrm{mg} \mathrm{L}^{-1}\right)$, and average removal percentage was $9.6 \%$ (Fig. 4). On three occasions, treated water had higher DOC concentrations than raw water samples highlighting that the GAC filter itself was a source of NOM of up to $1.51 \mathrm{mg} \mathrm{L}^{-1}$ (Fig. 4). GAC removal efficiency of NOM has been shown to be most dependent on regeneration (Matilainen et al. 2006), and the GAC filter in this study, installed in 2011, had never been regenerated. Facilities for regeneration are not in situ in Ireland and were material to be regenerated, it would have to be transported to the UK, which would not be economically viable. Adsorption of lower molecular weight NOM has been shown to decrease after oxidation owing to polarity and formation of carbonyls and carboxyl groups upon ozonation and therefore does not absorb onto the GAC surface (Swietlik et al. 2002). The average $\mathrm{UVA}_{254}$ value was $0.20 \mathrm{~cm}^{-1}\left(0.06-0.48 \mathrm{~cm}^{-1}\right)$ at the raw water, $0.13 \mathrm{~cm}^{-1}\left(0.03-0.39 \mathrm{~cm}^{-1}\right)$ post-ozone and $0.10 \mathrm{~cm}^{-1}$ $\left(0.03-0.26 \mathrm{~cm}^{-1}\right)$ following GAC filtration (Fig. 9). Average reduction percentage by ozone treatment was $34 \%$, and the GAC contributed to a further reduction percentage of $21 \%$ (except on three occasions where an increase in $\mathrm{UVA}_{254}$ was observed, August and December 2014 and February 2015) (Fig. 9). Ozone treatment decreases hydrophobic molecules by creating carbonyls such as formaldehyde which lowers the absorbance and the fluorescence but can create other problems in terms of taste (Sohn et al. 2007).

Average SUVA for raw water was $3.2 \mathrm{~L} \mathrm{mg}^{-1} \mathrm{~m}^{-1}$, an indication of NOM of moderate aromaticity, and GAC has
Fig. $11 \mathrm{~F}_{\max }$ percentage reduction following ozone (hatched) and GAC (grey) treatment
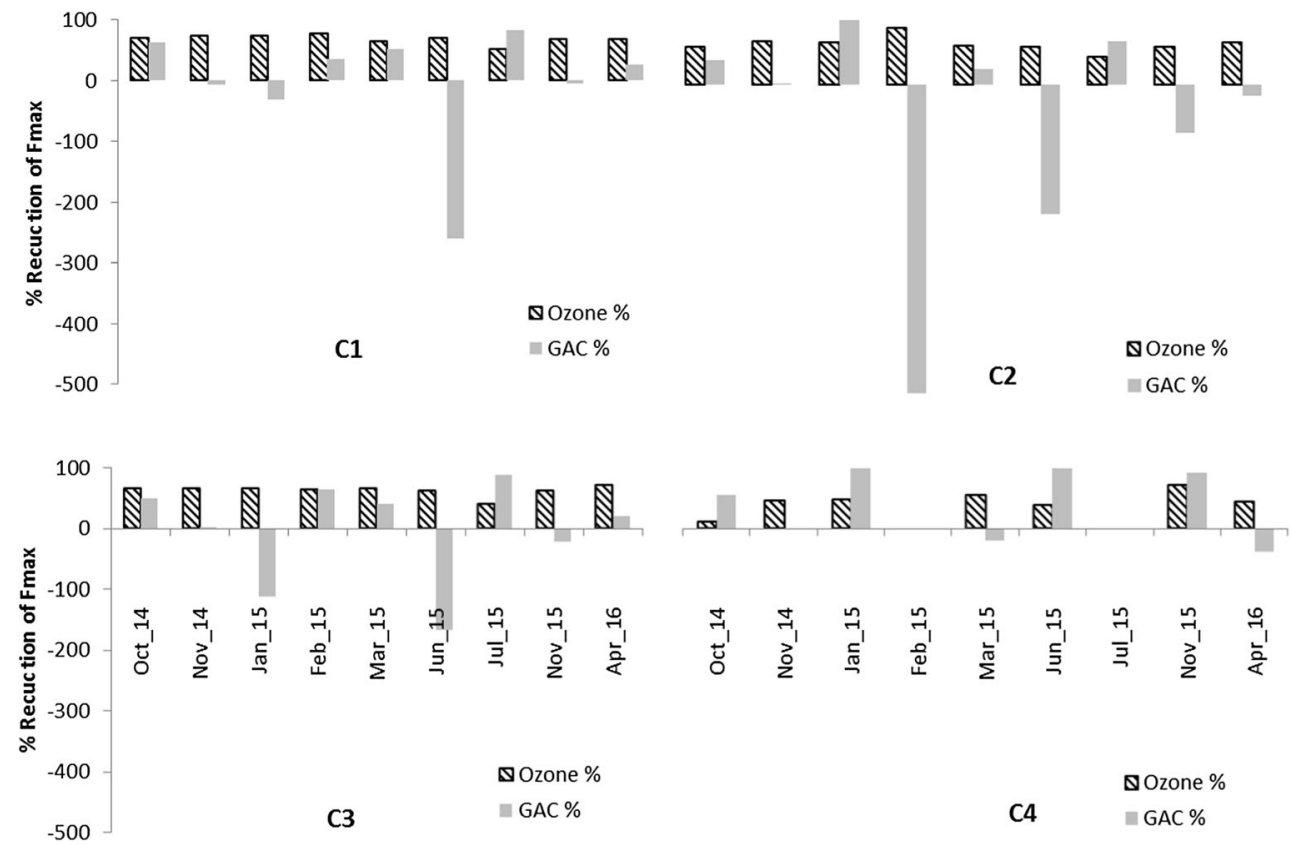
Table 3 Summary of Spearman's rank correlation coefficients between DOC concentrations, $U_{V A} 254$ absorbance, SUVA, total nitrogen, chloroform $(\mathrm{CHCl} 3)$, bromoform $(\mathrm{CHBr} 3)$, bromodichloromethane $(\mathrm{CHBr} 2 \mathrm{Cl})$, dibromochloromethane $(\mathrm{CHBrCl} 2)$, total THMs and PARAFAC component scores

\begin{tabular}{|c|c|c|c|c|c|c|c|c|c|c|c|c|c|}
\hline & DOC & $\mathrm{UVA}_{254}$ & SUVA & $\mathrm{C} 1$ & $\mathrm{C} 2$ & $\mathrm{C} 3$ & $\mathrm{C} 4$ & $\mathrm{TN}$ & $\mathrm{CHCl} 3$ & $\mathrm{CHBr} 3$ & $\mathrm{CHBr} 2 \mathrm{Cl}$ & $\mathrm{CHBrCl} 2$ & Total THMs \\
\hline DOC & 1 & $0.72 *$ & & $0.72 *$ & $0.49 *$ & $0.67 *$ & & & & & $-0.53 *$ & & \\
\hline $\mathrm{UVA}_{254}$ & & 1.00 & $0.62 *$ & $0.82 *$ & $0.56^{*}$ & $0.69^{*}$ & & $0.52^{*}$ & $0.64 *$ & & $-0.52 *$ & & $0.61 *$ \\
\hline SUVA & & & 1.00 & & & & & & $0.48 *$ & & & & \\
\hline $\mathrm{C} 1$ & & & & 1.00 & $0.56^{*}$ & $0.77 *$ & & & $0.57^{*}$ & & $-0.65^{*}$ & & $0.56^{*}$ \\
\hline $\mathrm{C} 2$ & & & & & 1.00 & & & & $0.53 *$ & & $-0.49^{*}$ & & $0.49 *$ \\
\hline $\mathrm{C} 3$ & & & & & & 1.00 & & & $0.52 *$ & & $-0.49 *$ & & \\
\hline $\mathrm{C} 4$ & & & & & & & 1.00 & & & & & & \\
\hline $\mathrm{TN}$ & & & & & & & & 1.00 & $0.62 *$ & & & & $0.63 *$ \\
\hline $\mathrm{CHCl} 3$ & & & & & & & & & 1.00 & & & $0.62 *$ & $0.93 *$ \\
\hline $\mathrm{CHBr} 3$ & & & & & & & & & & 1.00 & & & \\
\hline $\mathrm{CHBr} 2 \mathrm{Cl}$ & & & & & & & & & & & 1.00 & & \\
\hline $\mathrm{CHBrCl} 2$ & & & & & & & & & & & & 1.00 & $0.71^{*}$ \\
\hline Total THMs & & & & & & & & & & & & & 1.00 \\
\hline
\end{tabular}

been shown to be most effective for removal of NOM in this range (Matilainen et al. 2006). SUVA in the finished water was $1.8 \mathrm{~L} \mathrm{mg}^{-1} \mathrm{~m}^{-1}$, which is typical of NOM with low aromaticity (SUVA $<2 \mathrm{~L} \mathrm{mg}^{-1} \mathrm{~m}^{-1}$ ). On five occasions, SUVA was greater than $2 \mathrm{~L} \mathrm{mg}^{-1} \mathrm{~m}^{-1}$, a parametric value specified above which THMs are likely to form (EPA 2012). E2/E3 ratios and SR revealed increases following ozonation with no further increases following GAC treatment demonstrating a decrease in molecular weight with treatment.

Fmax was higher for terrestrial and ubiquitous humic-like component $\mathrm{C} 1$ in the raw water followed by $\mathrm{C} 2, \mathrm{C} 3$ and $\mathrm{C} 4$ (Fig. 10). Ozonation decreased the fluorescence intensity of all humic-like components (C1, C2 and C3). GAC marginally decreased the fluorescence intensity in the terrestrial-derived humic-like components however was ineffective for the terrestrial-delivered reprocessed organic matter $(\mathrm{C} 2)$ and the protein-like microbial-delivered organic matter (C4). These findings are consistent with previous studies (Baghoth 2012; Shutova et al. 2014).

To evaluate the effect of water treatment on fluorescence characteristics of NOM, the percentage reduction of Fmax across each treatment process (Fig. 11) was calculated. Ozone reduced $\mathrm{C} 1$ by an average of $69 \%( \pm 7 \%)$ across all sampling occasions. $\mathrm{C} 2, \mathrm{C} 3$ and $\mathrm{C} 4$ were reduced by $64 \%( \pm 11 \%), 64 \%( \pm 8 \%)$ and $46 \%( \pm 17 \%)$, respectively. The GAC filtered reduced $\mathrm{C} 1$ by an average of $-4 \%( \pm 96 \%)$, $\mathrm{C} 2,-61 \%( \pm 172 \%), \mathrm{C} 3,-4 \%( \pm 80 \%)$ and $\mathrm{C} 4,41 \%( \pm 56 \%)$. Negative reductions indicate incidents where the GAC filter increased the Fmax of $\mathrm{C} 1, \mathrm{C} 2$ and $\mathrm{C} 3$ on certain occasions in the treated water highlighting that the filter media itself was a 'source' of NOM.

The average total THM (TTHM) concentration measured in the treated water was $88.8 \mu \mathrm{g} \mathrm{L}^{-1}\left(31.8-251 \mu \mathrm{g} \mathrm{L}^{-1}\right)$. Chloroform was the most prominent THM (average $~ 72 \%$ ) across all samples taken, followed by bromodichloromethane $(\sim 20 \%)$, dibromochloromethane $(\sim 6 \%)$ and bromoform $(<$ $1 \%)$. Average TTHMs across the distribution network displayed similar temporal changes as DOC with ambient temperature and local rainfall. Average free and total chorine concentrations were 0.98 and $1.22 \mathrm{mg} \mathrm{L}^{-1}$. The average DOC concentration measured from 9 locations along the distribution network was $5.59 \mathrm{mg} \mathrm{L}^{-1}$. At DOC $>4.0 \mathrm{mg} \mathrm{L}^{-1}$, it is likely that THM levels will exceed $100 \mu \mathrm{g} \mathrm{L}{ }^{-1}$ if the residence time in the network is $2-3$ days and if a free residual chlorine is to be maintained at the tap (EPA 2012). C2 had the highest fluorescence intensity in the distribution network followed by $\mathrm{C} 1$ and C3. THMs exceeded the parametric value in $45 \%$ of samples taken.

All samples from the post-treatment and distribution network were included in the determination of Spearman's correlation coefficients (Table 3). There were significant correlations among DOC; $\mathrm{UVA}_{254}$ SUVA; PARAFAC components $\mathrm{C} 1, \mathrm{C} 2$ and $\mathrm{C} 3$; $\mathrm{TN}$, chloroform $(\mathrm{CHCl} 3)$; bromodichloromethane (CHBr2Cl); dibromochloromethane $(\mathrm{CHBrCl} 2)$; and total THMs. UVA254 and $\mathrm{C} 1$ had equal correlation scores (0.72) to DOC. TN was significantly correlated with $\mathrm{UVA}_{254}$ and chloroform. It is likely that runoff from the farming activities indicated by high TN and chloroform and also the 'terrestrialdelivered reprocessed organic matter' is the cause for the high correlation. $\mathrm{C} 1, \mathrm{C} 2$ and $\mathrm{C} 3$ were significantly correlated with $\mathrm{UVA}_{254}$ and chloroform. SUVA was not significantly correlated with any of the PARAFAC components.

GAC has previously been shown to act as a removal medium for metals in water streams (Dong et al. 2018; Sounthararajah et al. 2016). As outlined in 2.2, the collected water samples were analysed for elemental composition prior to treatment (raw water) and also following combined ozone treatment and GAC filtration. The changes in concentrations 
of the different elements following the treatment processes are presented in Table S1. As previously noted, none of the water samples analysed exceeded the permissible limits of the EU Drinking Water Regulations (EU 2014). The elemental analysis did however show that the treatment failed to consistently reduce the concentration of the elements under investigation. Total nitrogen is the only parameter that consistently showed a reduction in concentration following treatment on all sampling events. All other elemental parameters monitored showed an inconsistent concentration variation following treatment, with both decreasing and increasing concentrations evident on different sampling occasions. For example, lead concentrations were found to be well below the limit value of $10 \mu \mathrm{g} / \mathrm{L}$ (EU 2014), in all samples of both raw and treated water with the highest concentrations of 0.85 and $0.52 \mu \mathrm{g} / \mathrm{L}$, respectively, in the raw and treated water recorded on 27/03/ 2015. The treatment process however did not consistently remove lead $(\mathrm{Pb})$ from the water with the treated water having higher concentrations on a number of occasions (31/07/2015, $29 / 08 / 2015,29 / 09 / 2015,30 / 10 / 2015$ and $27 / 11 / 2015)$ than the raw water.

As was previously observed, DOC concentrations were also found to increase following GAC filtration, on certain sampling events which highlights the potential for the GAC itself to act as a source of NOM as the GAC may become exhausted following periods of increased NOM concentrations. It is therefore possible that the GAC may also release some previously captured elemental species in a similar fashion. It has previously been noted in laboratory studies that GAC has a maximum capacity for different elemental species and that the adsorption of elements by charcoal is influenced by DOC concentrations and turbidity levels (Jusoh et al. 2007; Sounthararajah et al. 2015).

In terms of the elemental composition of the water itself, the water was found to have average concentrations for the major cations of $9.75 \mathrm{mg} / \mathrm{L}(\mathrm{Na}), 2.41 \mathrm{mg} / \mathrm{L}(\mathrm{K}), 103.99 \mathrm{mg} / \mathrm{L}$ $(\mathrm{Ca})$ and $6.49 \mathrm{mg} / \mathrm{L}(\mathrm{Mg})$, and it is indicative of water sourced from a limestone region (Graham and Farmer 2007). This is as expected as the water in the WPWS is from a spring source in a karst area.

\section{Conclusion}

Groundwater, where adequate supply is available, is viewed as a preferable option to surface water in Ireland owing to the challenge posed by treating surface water (O'Dwyer et al. 2014). Online raw water UV transmission (UVT) monitors can be accurately used as indicators of the extent of surface water infiltration and potential for microbial contamination, which can inform suitable treatment options or scoping of an alternative source. UVT is related to the quantity of organic solids and other material in the water which cause UV light to absorb and scatter as it passes through the water column. Water quality parameters, SUVA and F-EEMs, indicate that this spring source is highly comparable with surface water and E2:E3 ratios allow for targeted selection of activated carbon range, i.e. microporous or mesoporous. However, even with targeted selection, mechanisms must be put in place for replacement/regeneration of filter media once it has been shown to become exhausted to avoid repeated THM exceedances as observed in this supply. Furthermore, identification of the quality of NOM is important prior to treatment design as in this instance pre-ozonation followed by GAC was not adequate to remove the NOM indicative of lower SUVA and lower molecular weight. Additionally, SPAs and SPZs rather than ZoCs should be considered in risk assessment of raw drinking water.

As previously shown in Irish supplies, chloroform was the most prominent THM (O'Driscoll et al. 2018). C2, the terrestrial-delivered reprocessed organic matter, was responsible for majority of THM production in the distribution network. Treatment failed to consistently reduce the concentration of the elements under investigation. Total nitrogen is the only parameter that consistently showed a reduction in concentration following treatment on all sampling events. All other elemental parameters monitored showed an inconsistent concentration variation following treatment, with both decreasing and increasing concentrations evident on different sampling occasions.

Acknowledgements We wish to thank the local authorities and water managers who allowed access to the Water Treatment Plant and Sean Quinn, Dave Donlon, Declan Mannion and Eugene Quigley, Galway County Council, for assistance with sample collection.

Funding information This work was funded by the Environmental Protection Agency (EPA) under the Water - EPA Research Strategy 2014e2020 programme (grant number 2013-W-MS-14).

\section{References}

Baghoth SA (2012) Characterizing natural organic matter in drinking water treatment processes and trains. PhD Thesis, UNESCO-IHE

Baghoth SA, Sharma SK, Amy GL (2011) Tracking natural organic matter $(\mathrm{NOM})$ in a drinking water treatment plant using fluorescence excitation-emission matrices and PARAFAC. Water Res 45:797809. https://doi.org/10.1016/j.watres.2010.09.005

Brennan RB, Clifford E, Devroeddt C, Morrison L, Healy MG (2017) Treatment of landfill leachate in municipal wastewater treatment plants and impacts on effluent ammonium concentrations. J Environ Manag 188:64-72

Brooks E, Freeman C, Gough R, Holliman PJ (2015) Tracing dissolved organic carbon and trihalomethane formation potential between source water and finished drinking water at a lowland and an upland UK catchment. Sci Total Environ 537:203-212. https://doi.org/10. 1016/j.scitotenv.2015.08.017 
Catalá TS, Reche I, Fuentes-Lema A, Romera-Castillo C, Nieto-Cid M, Ortega-Retuerta E, Calvo E, Álvarez M, Marrasé C, Stedmon CA, Álvarez-Salgado XA (2015) Turnover time of fluorescent dissolved organic matter in the dark global ocean. Nat Commun 6(1)

Cawley KM, Ding Y, Fourqurean J, Jaffé R (2012) Characterising the sources and fate of dissolved organic matter in Shark Bay, Australia: a preliminary study using optical properties and stable carbon isotopes. Mar Freshwater Res 63(11): 1098

Chow CWK, van Leeuwen JA, Drikas M, Fabris R, Spark KM, Page DW (1999) The impact of the character of natural organic matter in conventional treatment with alum. Wat Sci Techn 40(9):97-104

Coble PG (1996) Characterization of marine and terrestrial DOM in seawater using excitation-emission matrix spectroscopy. Mar Chem 51:325-346

Dong L, Hou L, Wang Z, Gu P, Chen G, Jiang R (2018) A new function of spent activated carbon in BAC process: removing heavy metals by ion exchange mechanism. J Hazard Mater 359:76-84. https://doi. org/10.1016/j.jhazmat.2018.07.030

EPA (2011a) EPA Drinking Water Advice Note: Advice Note No. 7: Source Protection and Catchment Management to protect Groundwater Supplies. Version 1, Issued 02/08/2010. https://www. epa.ie/pubs/advice/drinkingwater/Advice\%20Note\%20No7.pdf

EPA (2011b) Site Information Report, Williamstown PS. https://www. epa.ie/pubs/reports/water/ground/gwmpinfo/EPA_DWZOC_ Williamstown\%20PS.pdf accessed on the 13/02/2017

EPA (2012) EPA Drinking Water Advice Note. Disinfection ByProducts in Drinking Water, Advice Note No. 4, Version 2, 2012; 1-27. http:// www.epa.ie/pubs/advice/drinkingwater/DrinkingWaterGuide4_v8. pdf

European Commission, 2014. Synthesis Report on the Quality of Drinking Water in the EU examining the Member States' reports for the period 2008-2010 http://ec.europa.eu/environment/water/ water-drink/reporting_en.html

European Commission, 2018. Revision of the Drinking Water Directive. https://eur-lex.europa.eu/legal-content/EN/TXT/?uri=COM\% 3A2017\%3A753\%3AFIN

European Union, (Drinking Water) Regulations 2014. http://www. irishstatutebook.ie/eli/2014/si/122/made/en/pdf

Graham MC, Farmer JG (2007) Chemistry of freshwaters in 'principles of environmental chemistry'. Royal Society of Chemistry, Cambridge, pp 80-169

Healy M, Cawley AM (2002) Nutrient processing capacity of a constructed wetland in Western Ireland. J Environ Qual 31:1739-1747

Hunter Williams N, Kelly C, Daly D (2017) Know your ZOCs from your SPAs - groundwater source protection terminology and usage. International Association of Hydrologeologists - Irish group annual. Hydrogeology in a chaniging water services and planning environment. Proceedings of the 37th annual groundwater conference Tullamore, co. Offaly, Ireland. 25th and 26th April 2017. http:// www.iah-ireland.org/conference-proceedings/2017.pdf

IBM Corp. Released (2013) IBM SPSS statistics for windows, version 22.0. IBM Corp, Armonk

Jusoh A, Shiung LS, Ali N, Noor MJMM (2007) A simulation study of the removal efficiency of granular activated carbon on cadmium and lead. Desalination 206(1-3):9-16. https://doi.org/10.1016/j.desal. 2006.04.048

Kowalczuk P, Durako MJ, Young H, Kahn AE, Cooper W, Gonsior M (2009) Characterization of dissolved organic matter fluorescence in the South Atlantic Bight with use of PARAFAC model: Interannual variability. Mar Chem 113(3-4):182-196

Krasner SW (2009) The formation and control of emerging disinfection by-products of health concern. Phil Trans R Soc 367:4077-4095

Krasner SW, McGuire MJ, Jacangelo JG, Patania NL, Reagan KM, Aieta EM (1989) The occurrence of disinfection by products in United States drinking water. J Am Water Works Assoc 81:41-53
Kraus TEC, Anderson CA, Morgenstern K, Downing BD, Pellerin BA, Bergamaschi BB (2010) Determining sources of dissolved organic carbon and disinfection byproduct precursors to the McKenzie River, Oregon. J Environ Qual 39:2100-2112. https://doi.org/10. 2134/jeq2010.0030

Lambert T, Bouillon S, Darchambeau F, Massicotte P, Borges AV (2016) Shift in the chemical composition of dissolved organic matter in the Congo River network. Biogeosciences 13(18):5405-5420

Lawaetz AJ, Stedmon CA (2009) Fluorescence intensity calibration using the Raman scatter of water. Appl Spectrosc 63(8):936-940

Li X-F, Mitch WA (2018) Drinking water disinfection byproducts (DBPs) and human health effects: multidisciplinary challenges and opportunities. Environ. Sci. Technol. 52:1681-1689

Li R, Kelly C, Keegan R, Xiao L, Morrison L, Zhan X (2013) Phosphorus removal from wastewater using natural pyrrhotite. Colloids Surf A Physicochem Eng Asp 427:13-18

Lipczynska-Kochany E (2018) Effect of climate change on humic substances and associated impacts on the quality of surface water and groundwater: a review. Sci Tot Environ 640-641:1548-1565

Matilainen A, Vineo M, Tuhkann T (2006) Efficiency of the activated carbon filtration in the natural organic matter removal. Environ Int 32:324-331

McGrory ER, Brown C, Bargary N, Hunter Williams N, Mannix A, Zhang C, Henry T, Daly E, Nicholas S, Petrunic BM, Lee M, Morrison L (2017) Arsenic contamination of drinking water in Ireland: a spatial analysis of occurrence and potential risk. Sci. Tot. Environ. 579:1863-1875

McGrory E, Holian E, Alvarez-Iglesias A, Bargary N, McGillicuddy E, Henry T, Daly E, Morrison L (2018) Arsenic in groundwater in south West Ireland: occurrence, controls and hydrochemistry. Frontiers in Environmental Science 6:154. https://doi.org/10.3389/ fenvs.2018.00154

Menichini M, Da Prato S, Doveri M, Ellero A, Lelli M, Masetti G, Nisi B, Raco B (2015) An integrated methodology to define protection zones for groundwater based drinking water sources: an example from the Tuscany region, Italy. Acque Sotterranee-Italian journal of groundwater, AS12058, 021-027

Mitchell E, Frisbie S, Sarkar B (2011) Exposure to multiple metals from groundwater - a global crisis: geology, climate change, health effects, testing and mitigation. Metallomics 3:874-908

Murphy KR, Butler KD, Spencer RGM, Stedmon CA, Boehme JR, Aiken GR (2010) Measurement of dissolved organic matter fluorescence in aquatic environments: an interlaboratory comparison. Environ Sci Technol 44:9405-9412

Murphy KR, Stedmon CA, Graeber D, Bro R (2013) Fluorescence spectroscopy and multi-way techniques. Anal Methods 5:6557-6566

Murphy KR, Stedmon CA, Wenig P, Bro R (2014) OpenFluor - an online spectral library of auto-fluorescence by organic compounds in the environment. Anal Methods 6:658-661

Murphy KR, Ruiz GM, Dunsmuir WTM, Waite TD (2006) Optimized parameters for fluorescence-based verification of ballast water exchange by ships. Environ Sci Technol 40(7):2357-2362

Naughton O, Johnston PM, Gill LW (2012) Groundwater flooding in Irish karst: the hydrological characterisation of ephemeral lakes (turloughs). J Hydrol 470-471:82-97. https://doi.org/10.1016/j. jhydrol.2012.08.012

O'Driscoll C, Sheahan J, Renou-Wilson F, Croot P, Pilla F, Misstear B, Xiao L (2018) National scale assessment of total trihalomethanes in Irish drinking water. J Environ Manag 212:131-141

O'Dwyer J, Dowling A, Adley CC (2014) Microbiological assessment of private groundwater-derived potable water supplies in the mid-west region of Ireland. J Water Health 12(2):310-317

Pathak A, Morrison L, Healy MG (2017) Catalytic potential of selected metal ions for bioleaching, and potential techno-economic and environmental issues: a critical review. Bioresour Technol 229:211221 
Pavlis M, Cummins E (2014a) Using total organic carbon for the assessment of groundwater vulnerability in karst regions at regional scales. Environ Earth Sci 72:1993-2007. https://doi.org/10.1007/s12665014-3415-2

Pavlis M, Cummins E (2014b) Assessing the vulnerability of groundwater to pollution in Ireland based on the COST-620 pan-European approach. J Env Man 133:162-173. https://doi.org/10.1016/j. jenvman.2013.11.044

Peyton DP, Healy MG, Fleming GTA, Grant J, Wall D, Morrison L (2017) Nutrient, metal and microbial loss in surface runoff following treated sludge and dairy cattle slurry application to an Irish grassland soil. Sci Total Environ 541:218-229

Pronk M, Goldscheider N, Zopfi J (2006) Dynamics and interaction of organic carbon, turbidity and bacteria in a karst aquifer system. Hydrogeol J 14(4):473-484

Redman AD, Macalady DL, Ahmann D (2002) Natural organic matter affects arsenic speciation and sorption onto hematite. Environ. Sci. Technol. 36:2889-2896

Reimann C, Filzmoser P, Garrett RG, Dutter R (2008) Statistical data analysis explained. Applied Environmental Statistics with R. John Wiley \& Sons Ltd., USA

Shutova Y, Baker A, Bridgeman J, Henderson RK (2014) Spectroscopic characterisation of dissolved organic matter changes in drinking water treatment: From PARAFAC analysis to online monitoring wavelengths. Water Res 54:159-169

Sohn J, Amy G, Yoon Y (2007) Process-train profiles of NOM through a drinking water treatment plant. J AWWA 99(6):145-153

Sounthararajah D, Loganathan P, Kandasamy J, Vigneswaran S (2015) Effects of humic acid and suspended solids on the removal of heavy metals from water by adsorption onto granular activated carbon. Int J Environ Res Public Health 12(9):10475-10489. https://doi.org/10. 3390/ijerph120910475

Sounthararajah D, Loganathan P, Kandasamy J, Vigneswaran S (2016) Column studies on the removal of dissolved organic carbon, turbidity and heavy metals from stormwater using granular activated carbon. Desalin Water Treat 57(11):5045-5055. https://doi.org/10. 1080/19443994.2014.999717
Stedmon CA, Markager S, Bro R (2003) Tracing dissolved organic matter in aquatic environments using a new approach to fluorescence spectroscopy. Mar Chem 82:239-254

Stedmon CA, Thomas DN, Granskog M, Kaartokallio H, Papadimitriou S, Kuosa H (2007) Characteristics of dissolved organic matter in Baltic Coastal Sea Ice: Allochthonous or Autochthonous Origins? Environ Sci Technolo 41(21):7273-7279

Swietlik J, Raczyk-Stanislawiak U, Bilozor S, Ilecki W, Nawrocki J (2002) Effect of oxidation with chlorine dioxide on the adsorption of natural organic matter on granular activated carbon. Pol J Environ Stud 11(4):435-439

ter Braak CJF, Šmilauer P (1998) CANOCO reference manual and user's guide to Canoco for windows: software for canonical community ordination (version 4). Microcomputer Power, Ithaca, p 352

Walker SA, Amon RMW, Stedmon CA (2013) Variations in high-latitude riverine fluorescent dissolved organic matter: A comparison of large Arctic rivers. J Geophys Res: Biogeosci 118(4):1689-1702

Walker SA, Amon RMW, Stedmon C, Duan S, Louchouarn P (2009) The use of PARAFAC modeling to trace terrestrial dissolved organic matter and fingerprint water masses in coastal Canadian Arctic surface waters. J Geophys Res 114

Weishaar JL, Aiken GR, Bergamaschi BA, Fram MS, Fugii R, Mopper K (2003) Evaluation of specific ultraviolet absorbance as an indicator of the chemical composition and reactivity of dissolved organic carbon. Environ. Sci. Technol. 37:4702-4708

Weng L, Riemsdijk WHV, Hiemstra T (2009) Effects of fulvic and humic acids on arsenate adsorption to goethite: experiments and modeling. Environ. Sci. Technol. 43:7198-7204

Williams CJ, Frost PC, Xenopoulos MA (2013) Beyond best management practices: pelagic biogeochemical dynamics in urban stormwater ponds. Ecol Appl 23(6):1384-1395

WHO (2011) Guidelines for drinking-water quality, 4th edn. World Health Organization, Geneva

Publisher's note Springer Nature remains neutral with regard to jurisdictional claims in published maps and institutional affiliations. 